\title{
The Enviroment Education in Pratice: Challenges ahead Legislation
}

\author{
Maria Cristina Delmondes \\ Nascimento $^{1}$; \\ George Gomes de Amorim ${ }^{2}$
}

\begin{abstract}
This study discusses the environmental education in practice and the challenges faced by teachers before the law. This is a field study, exploratory in nature, where it is intended to reflect the effectiveness of environmental education in pedagogical practice, together with teachers from schools in Araripina, State of Pernambuco, Brazil. The starting point is the teachers' perception about the pedagogical practice related to environmental education. 45 teachers were interviewed, through a previously structured script. The answers showed that, although they have an academic background at the level of specialization lato sensu, the teachers do not have specific training to work with the transversal themes planned, especially with the theme Environmental Education, as required by the legislation. The teachers' perception points to the need for a more specific training in terms of the environment, in addition to another, more focused on the reflection on the importance of strengthening human values, to strengthen the construction of citizen subjects.
\end{abstract}

Keywords: Teaching practice. Environmental education. Educational legislation.

\section{Introduction}

Environmental Education is a subject that requires some urgency of educational, social and governmental practices aiming at the preservation and maintenance of what remains of the natural resources for the future generation. Compliance with laws - be they any follow-up - does not always happen for everyone involved either for ignorance, or for the fact that there is no punishment for their non-compliance.

The teacher plans, directs and controls the teaching process, to stimulate and stimulate the student's own activity for learning (Libâneo, 1994).

\footnotetext{
${ }^{1} \mathrm{PhD}$ student in Education; Master in Science of Education; Specialization in Public Policies and Teaching of Higher Education; Specialization in Environmental Education; Degree in Biological Sciences from the Federal University of the São Francisco Valley (2014); Graduation in Pedagogy by Evangelical Faculty of Piauí, (2012) Graduation in Agronomic Engineering by Faculty of Agricultural Sciences of Araripina (2010); Educational coordinator; Professor of the pedagogical department of the Ruymar Gomes Educational Institute, teacher of the Dionísio Bom de Oliveira School, Lecturer - WEJ Consultoria, professor of the pedagogical department - WEJ Consultoria; Professor of the pedagogical department - CETECS BRASIL, professor of the pedagogy course of the Regional Faculty of Riachão do Jacuipe and Professor of the Faculty of Teacher Training of Araripina. cristina_delmondes@hotmail.com

${ }^{2}$ Graduated in Physical Education by the Jaguaribe Valley College - FVJ.
} 
Thus, the teacher is the agent capable of helping the child to understand the meaning of EE (Environmental Education) for your life. According to Tebar (211, p. 95), this professional must be attentive to the three requirements of meaning: 1) to arouse in the child an interest in the task itself; 2) to talk with the subject about the importance of such a task; 3 ) explain to you what the desired goal is with the activities and their application.

The National Plan for Environmental Education - Law 9795/99, states in its Article 2, that "Environmental Education is an essential and permanent component of National Education, and must be present, in an articulated way, at all levels and modalities of the educational process, on a formal and non-formal basis ". Thus, the teacher is the individual who, legally, must watch over compliance with this article, since he represents the professional who holds the free will to choose his practices and consequently, with articulation quoted in the law.

Article 3, item II of the same Law, quoted above, complements the idea when affirming that it is the responsibility of "educational institutions to promote Environmental Education in an integrated way to the educational programs that they develop". Further, Article 9 clarifies: "Environmental Education in School Education is understood to be developed within the curricula of public and private educational institutions, including: I Basic Education: a) Infant Education; B) Fundamental Education and c) Secondary Education; II - Higher Education; In the modalities: III - Special Education; IV - Vocational Education; V - Youth and Adult Education ". Understanding that it is in the elementary education, that is, in the first years of schooling that the child is open, with more facility for apprehension and association between theory and practice, it is necessary to investigate how it is being incorporated in children and adolescents Importance that the teaching of Environmental Education brings in social, collective, ethical, moral formation.

Therefore, this research intends to perform a synthesis on how educators perceive the EA in the school's objects of the present study. Hence the desire to understand and discuss teacher's practices about EE. 


\section{Environmental Education in School Space}

The school environment is a privileged space for the teaching of EE, it's in it that, from childhood, it is intended to awaken in the human being the collective conscience focused on preservation and respect for the environment. However, this articulation must be present, in an integrated way, in every educational process, and today it is pertinent that school curricula seek to develop environmental pedagogical practices.

Presenting EE to students by public or private institutions is not an option, it is covered by law, including by the supreme law (Federal Constitution), which in its article 225, chapter IV, referring to the Environment, states that Public Power is In charge of "promoting environmental education at all levels of education and public awareness for the preservation of the environment", but it is visible the lack of preparation of education professionals to put into practice the real objective of $\mathrm{EE}$, among which are: The encouragement of individual and collective participation, permanent and responsible, in preserving the balance of the environment, with the defense of environmental quality as an inseparable value of the exercise of citizenship "(Article 5, item IV) as well as knowledge of Legislation governing this topic.

To teach in a coherent way it is necessary to know the law, otherwise this action will be carried out in a disjointed way.

\footnotetext{
Environmental education in school education is understood to be developed within the curricula of public and private educational institutions, including: I - basic education: a) child education; B) basic education and c) secondary education; II - higher education; III - special education; IV - professional education; V - education of young people and adults. (Law No. 9.795, of April 27, 1999. Article 9th)
}

In order to comply with this article, it is of the utmost importance that the school space be open to the desire to carry out such development, with a view to effective actions. It is not difficult to perceive that the main solution comes from the educational field, requiring that all - governments, universities, - go hand in hand, with common goals; (Mathematics, Science, History, Geography, and Arts) - since EE cannot be seen as a specific discipline in teaching curricula, except in postgraduate courses, extension And in the areas focused on methodological aspects when necessary, as the National Environmental Education Policy in 
its article X, and to complete the NCPs referring to the Environment and Health in volume 9, page 49, states:

\begin{abstract}
The areas of Natural Sciences, History and Geography will be the main partners for the development of the contents related here, by the very nature of their objects of study. The areas of Portuguese Language, Mathematics, Physical Education and Art gain fundamental importance as they are basic tools for the student to conduct his / her process of building knowledge about the environment.
\end{abstract}

And on transversally states that:

The contents of the Environment will be integrated into the curriculum through transversally, as they will be treated in the different areas of knowledge, to permeate the entire educational practice and, at the same time, create a global and comprehensive vision of the environmental issue

The conscious action of teaching demands clarity with the educational objectives and coherence with its pedagogical operability, so the choice to work with the EE theme is accompanied by the need to acquire knowledge and information on the part of the teachers of the school only to develop a suitable work with the students. Due to the dimension of the environmental issue, it is necessary to seek information on the subject by all involved in the teaching-learning process. This does not mean that the school community should have all the knowledge about the subject, but rather be willing to arrest the subject and "convey to its students the notion that the process of building and producing knowledge is constant" (PCN Environment and Health, vol. 9, p.47)

Article 156 of the Organic Law of the Municipality of Araripina contains the following statement: "School curricula will be adapted to the peculiarities of the Municipality and the valuation of its historical, artistic, cultural and environmental heritage." Curriculum will include notions of ecology and environment, aiming to fight for the preservation of local fauna and flora. It is very important to transmit this information in law to teachers, guiding them to follow a path consistent with their practices.

The general objective of this study was to discuss the effectiveness of environmental education in the pedagogical practice of teachers from two schools in the city of AraripinaPE. It was also believed necessary: 1) To identify the socio-demographic profile of the subjects in the sample; 2) To know the projects of environmental education developed in the school's object of the present study; 3) Discuss the strategies that teachers use to develop 
activities focused on environmental issues; And 4) To know the difficulties cited by teachers for the implementation of environmental education activities.

\section{Method}

It is a field study, descriptive, qualitative approach, but also associates the quantitative form, in relation to some variables.

Araripina was the municipality selected for the survey. It is known as the city of gypsum, since it is responsible for 95\% of the gypsum consumed in Brazil (Araripina, Wikipedia), possessing the fifth largest GDP of the Pernambuco backwoods, on the other hand the production of gypsum causes: air pollution; deforestation; Soil degradation; Erosion, etc. Thus, presenting the urgency of educational and public policies that work hand in hand to preserve and avoid damages caused by the production and use of gypsum locally and commonly globally.

Currently the municipality has 123 public and 9 private schools.

There are few schools that present pedagogical actions in line with the assumptions of $\mathrm{EE}$, an absence that motivates a greater social and environmental concern with the locality in question.

Dionísio Bom de Oliveira and Moisés Bom de Oliveira were chosen as the locus of the research, since they are the only two schools located in the district of Moraes, Araripina-PE. A place that is visibly devoid of environmental practices, which encourages us to understand why those institutions do not effectively comply with the laws that govern EE compliance.

The Dionísio Bom de Oliveira School (EDBO) is part of the 123 municipal public schools of Araripina-PE, it has on average a total of 460 students divided in the classes of Early Childhood Education, Elementary School (1st year to 6th year). The institution executes three Government programs among them the MORE EDUCATION PROGRAM where it works in the counter shift offering the Environmental Education as macro field within which the students are taught Agenda 21 in the school, Education for Sustainability and School and / or Community Garden; Athlete in the School, even with all these instruments it is noticeable that the actions related to Environmental Education are developed timidly, almost absent, 
since observing informally note that these instruments are only passed on theoretically without practical effect.

The Moisés Bom de Oliveira School (EMBO) presents the State Secretariat of Education of the State of Pernambuco as a support entity, offering the levels of Elementary School in the final years and Secondary School, the Youth and Adult Education (EJA) and the Fundamental Crossing and average distributed in the three shifts morning, afternoon and night. EMBO as well as EDBO enjoy the MORE EDUCATION PROGRAM assisting in environmental actions.

\section{Research Subjects}

The sample corresponded to all 45 teachers from both schools. The Dionísio Bom de Oliveira School has a distinctive feature in its staff of teachers, in which all teachers are effective. Currently has 23 teachers (2013), all in the educational area. The Moisés Bom de Oliveira School has 22 teachers.

Considering the selection criteria, the teachers were interviewed according to a structured script that included a questionnaire (appendix E), which included the following aspects:

A) Identification of teachers regarding the sex, age, schooling, time of action in the area;

B) Conceptual questions about environmental education. These are: environmental education and sustainable development, as well as their importance;

C) Issues related to teachers' social representations on the subject; As well as their perceptions about contributions obtained with the implementation of the disciplines, difficulties in the maintenance of the classes and changes observed in the students.

\section{Results and Discussions}

To discuss the effectiveness of environmental education in the pedagogical practice of teachers in the municipality of Araripina-PE, was the purpose of the present study. 
The schools involved in the present study were: Dionísio Bom de Oliveira and Moisés Bom de Oliveira. Table 1 below shows the number of teachers involved in this research, per school.

Table 1: Distribution of Number of Teachers per School.

\begin{tabular}{lcc}
\hline Number of teachers per school & Frequency & Percentage (\%) \\
\hline Dionísio Bom de Oliveira & 23 & 51,0 \\
\hline Moisés Bom de Oliveira & 22 & 49,0 \\
\hline Total & $\mathbf{4 5}$ & $\mathbf{1 0 0 , 0}$ \\
\hline
\end{tabular}

Araripina - PE, 2014.

Following, and in compliance with the first specific objective, the data regarding the socio-demographic characterization of the sample, used in the present study, are demonstrated.

\section{Teacher's Profile}

This study included 45 teachers who did not oppose participation. All questionnaires were considered valid.

Regarding gender, the sample is mostly female educators, in number of 28 (62.2\%), 15 of them male (33.3\%). Two of the teachers did not answer this question (4.5\%).

Regarding the ages, the sample had the following distribution: 14 teachers aged between 21 and 30 years (31.1\%); 19 teachers aged 31-40 years (42.2\%) and 12 teachers over 40 years old $(26.7 \%)$. There are, therefore, relatively young teachers, in the range of 21 to 30 years, representing $31.1 \%$ of the sample. The other, more mature teachers together account for $68.9 \%$ of the sample, over 30 years of age.

Regarding schooling, the sample behaved as follows: 2 of the teachers had only high school (4.4\%); 3 were in the upper level (6.7\%); 3 already had a full course $(6.7 \%)$ and 35 had completed a specialization course $(77.8 \%)$. Only 2 teachers did not answer this question $(4.4 \%)$ 
Teacher training in Brazil is still considered unsatisfactory when it comes to more specific knowledge. There are some shortcomings, for example, when it comes to Environmental Education, because there is a prioritization in pedagogical knowledge for a theoretical formation, rather than practice (Cunha; Krasilchik, 2000).

In this sense, most of the educators in primary and secondary education in Brazilian public schools are general educators. Even in the case of the present research, "specialist" teachers do not always have the training to work on certain transversal themes, such as Environmental Education, in which they are charged to act.

Authors such as Meglhioratti, Bortolozzi and Caldeira (2005), as well as Bulos and Jesus (2006) guide us to a look that highlights the failures in the formation of this specific knowledge in the formation of the generalist teacher, especially for the initial series in Basic Education. In these cases, the authors reinforce the occurrence of serious conceptual problems, in contents of the discipline of Sciences, for example. In these cases, according to the authors Malacarne and Strieder (2009), the teachers of the initial grades have little or no specific education in sciences that supports their presence in this discipline. In many cases, presenting contents that are not related to the daily life and context of the students.

As for teaching time, there seems to be a good percentage of more experienced teachers, since $26.7 \%$ of the sample has between 6 and 10 years of teaching and $42.2 \%$ of the sample has more than 10 years of teaching.

Arroyo (2000) informs us that it is not only knowledge that is taught in school. But also, human skills, attitudes, and values. Inquiries that went on whether they like the profession of teacher, everyone was unanimous in saying yes, who like to act as educators. However, when asked about the possibility of changing professions, 24 teachers said yes $(53.3 \%)$, while 21 teachers said they would not do it (46.7\%).

It should be noted that, despite being unanimous in claiming that they enjoy the profession of teachers, $53.3 \%$ told us that if they could, they would change their profession. Which seems ambiguous to us.

It is possible that with limited training or, with little or no continuing education, more specific scientific knowledge, which understands the environment, can act as a disincentive to teachers. Also, the lack of support, space and material resources to carry out projects more daring and interesting, are a difficult in motivating them to continue in the profession. 
Subsequently, the subjects were asked about whether they developed any Environmental Education project in the school where they worked. The answers were that, $77.8 \%$ of the sample developed some type of environmental project in the school where they work, and $22.2 \%$ still do not.

\section{Environmental Projects Developed in Schools}

In response to the second specific objective, in relation to the Environmental Projects developed in the schools, the nature of these projects is described below.

Table 2: Distribution of Environmental Projects developed by Teachers

\begin{tabular}{lcc}
\hline Developed Environmental Projects & Frequency & Percentage (\%) \\
\hline Gardening Garden & 27 & 67,5 \\
\hline Awareness Lectures & 08 & 20,0 \\
\hline Recycling & 04 & 10,0 \\
\hline Visits & 01 & 2,5 \\
\hline Total & $\mathbf{4 0}$ & $\mathbf{1 0 0 , 0}$
\end{tabular}

Araripina - PE, 2014.

Of the $77.8 \%$ of the professors who affirmed to implement Environmental Projects in their school, $67.5 \%$ work with Horta and gardening; $20.0 \%$ facilitates awareness lectures; $10.0 \%$ works and stimulates recycling, and $2.5 \%$ work with visitation.

Also, $100.0 \%$ of the interviewees considered it important to implement the environmental theme in the curriculum.

Consulted if they were encouraged to develop environmental activities with their students, 32 answered yes (71.1\%); 12 answered No (97.8\%) and 1 did not answer this question $(2.2 \%)$.

When it comes to the development of environmental projects in the school environment, Donald Schon (1995) emphasizes the importance of this reflection in the teaching action. The author understands that such reflection in action helps in the formation of the researcher in the practical context. 


\section{Strategies used by Teachers for the Development of EE Related Activities}

In relation to the third specific objective, in relation to the strategies used by the teachers of the sample, to work with environmental issues in the classroom, it was observed that the most used was music (15.7\%), followed by debate and drawing (14\% and $14.0 \%$, respectively); The video was mentioned by $13.4 \%$ of the subjects and the games by $10.7 \%$. The tours $(7.5 \%)$ and the lectures $(7.0 \%)$. Less used as a strategy were the theater and educational panels with $4.8 \%$ each, separation of garbage $(3.8 \%)$ and booklets $(1.1 \%)$. Other strategies represented $3.2 \%$.

With regard to the strategies for project implementation and development in schools, Jacobi (2005) guides some principles in the construction of new teaching procedures, which are capable of integrating different resources in the didactic-pedagogical activities that aim at environmental education, as well as Preparing proposals or actions aimed at improving the quality of life of those involved or the community, namely: a) consider the ideas, interests and needs of those involved; B) To seek to promote the development of a continuous formation in the thematic; C) Allow individual and collective reflection on daily learning problems and difficulties; D) Facilitate the implementation of positive attitudes towards new environmental practices; E) To propose a transformation of the difficulties into challenges, taking into consideration the objectives proposed in the environmental education project of the school; And, F) Encourage the development of environmental education projects, both by teachers and students.

These principles presuppose that teacher training cannot be dissociated from a transformation of didactic-pedagogical procedures and a school attitude.

\section{Institutional Difficulties in the Implementation of Activities Related to Environmental Education}

The difficulties in implementing Environmental Education Activities were described as follows: 19 teachers cited support and resources (45.3\%); 10 cited provision and awareness on the part of educators themselves (23.8\%), 6 cited the issue of space for implementation of 
activities (14.3\%); 4 cited time as an impediment (9.5\%) and another 3 cited the lack of updated didactic material $(7.1 \%)$.

The challenge does not seem to be just to formulate a critical and innovative environmental education, but a kind of political act that is geared toward social transformation. For Sorrentino (1998), the development of values and behaviors (respect, trust, responsibility, honesty, commitment, solidarity and initiative) should be redeemed, as well as stimulating a global and critical view on environmental issues. Only with public policies that consider the importance of material, physical and human resources dedicated to citizen education, can we promote an interdisciplinary approach that will rescue and build knowledge in this thematic area.

Challenges to teachers have proved more practical. But one must bear in mind that the context in which environmental issues are framed tends to be marked by conflict of interest as well as a polarization between worldviews. The latter stemming from the new paradigms of development and globalization.

Thus, the challenge is not only to acknowledge but also to stimulate practices that reinforce and legitimize the autonomy of social actors in a cooperation perspective.

Asked whether the school has met the interdisciplinary goals of environmental education, the answers are set out in the following chart.

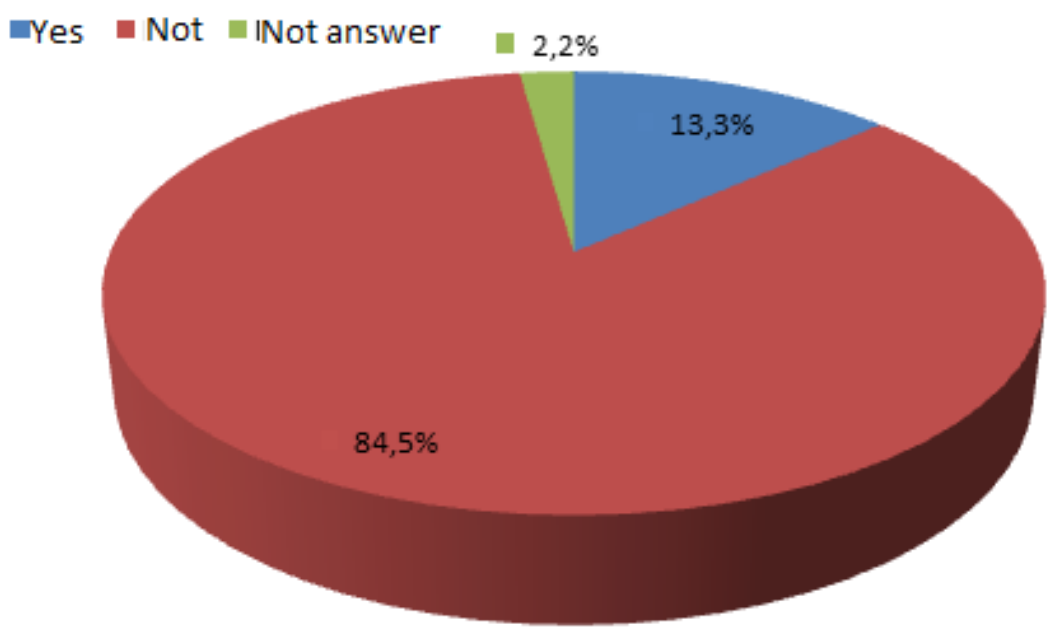

Graph 3 - Distribution of the answers when the school has reached the objectives Interdisciplinary approaches to Environmental Education 


\section{Final Considerations}

We work with environmental education to discuss the effectiveness of environmental education in the pedagogical practice of school teachers: Dionísio Bom de Oliveira and Moisés Bom de Oliveira, municipality of Araripina, Pernambuco, Brazil.

Given that Environmental Education is an important approach given the difficulties the planet is experiencing in its various dimensions, it is important to build this specific knowledge through reflections and discussions of experiences and possible actions. Teachers had the opportunity to put their social representations, perceptions and feelings. In its speeches, Environmental Education is an essential component, especially when it concerns an education of formation of human values, arousing a greater interest for the environment as a place of health promotion.

Environmental education was perceived by the subjects of the sample, as a process of education and permanent reflection, in the construction of citizen subjects. In education, its actions and educational practices should be aimed at raising the awareness of the community about emerging environmental issues, as well as their organization and participation, in the struggle for a better quality of the environment.

It is necessary to be more effective in the fight for public policies that will minimize the difficulties to implement and stimulate Environmental Education activities and projects. This implies making available adequate and adequate teaching materials, improving the physical structure of schools, financing the training of educators on the subject, as well as organizing in the curriculum, a time for teachers to be available for activities of this nature.

It is possible that the possibility of working with environmental practices more effectively would increase the autonomy of teachers and students in a social action that would probably benefit both the school and the community itself and the environment in which it operates. 


\section{References}

Arroyo, Miguel (2000). Ofício de mestre: imagens e auto-imagens. $3^{\text {a }}$ ed. Petrópolis: Vozes. (1998). Trabalho, educação e teoria pedagógica. In: FRIGOTTO, Gaudêncio (org.). Educação e crise do trabalho: perspectivas de final de século. $2^{\mathrm{a}}$ ed. Petrópolis: Vozes, p. 138-165.

. (org.) (1991). Da escola carente à escola possível. São Paulo: Loyola.

Brasil. (1988). Constituição da República Federativa do Brasil. Brasília: Senado.

(1981). Política Nacional do Meio Ambiente. Lei n. ${ }^{\circ} 6.938$ de 31 de agosto de 1981. Disponível em http://www.planalto.gov.br/ccivil_03/leis/16938.htm. Acessado em 15 de janeiro de 2013.

. (1996). LDB: Lei de diretrizes e Bases da Educação Nacional. Lei no 9.394, de 20 de dezembro de 1996, $9^{a}$ ed. - Brasília: Câmara dos Deputado.45 p

. (2013). Política Nacional de Educação Ambiental. Lei n. ${ }^{\circ}$ 9.795, 27 de abril de 1999. Disponível em http://www.planalto.gov.br/ccivil_03/leis/19795.htm. Acesso em: 16 jan 2013.

(2013). Secretaria de Educação Ambiental. Parâmetros Curriculares Nacionais. São Carlos - SP. Dissertação (mestrado em Educação) - Universidade Federal de São Carlos, São Carlos, 2003.

Cunha, A. M. O.; Krasilchik, M. (2000). A formação continuada de professores de ciências: percepções a partir de uma experiência. In: Reunião da Associação Nacional de PósGraduação d Pesquisa em Educação, 23. Caxambú. Anais... Caxambú: ANPED, p. 1-14.

Libâneo, José Carlos (1994). Didática. São Paulo: Ed. Cortez.

Malacarne, V.; Strieder, D. M. O desvelar da ciência nos anos iniciais do ensino fundamental: um olhar pelo viés da experimentação. Vivências, Erechim, v. 5, n. 7, p.75-85, 2009.

Meglhioratti, F. A.; BortolozzI, J.; Caldeira, A. M. A. (2005). Educação, conteúdo disciplinar e atitude crítica na formação de professores. Revista Científica Eletrônica de Pedagogia, Garça, n. 5, jan.

Ministério da Educação (2001). Secretaria da Educação Fundamental. Parâmetros Curriculares Nacionais - Meio Ambiente e Saúde. Brasília: MEC.

Ministério do Meio Ambiente (MMA). Agenda 21. Disponível em: www.mma.gov.br/sitio/index. php?ido=conteudo.monta\&idEstrutura=18. Acesso em: 04 de fevereiro de 2013.

Schön, Donald A.(1995). Formar professores como profissionais reflexivos, in Os professores e sua formação. Publicações Dom Quixote. 
Sorrentino, M.; Tbilisi A. ; Tessaloniki, A. (1998). A educação ambiental no Brasil. In: Jacobi, P. et. al. (orgs.). Educação, meio ambiente e cidadania: reflexões e experiências. São Paulo: SMA, p. 27-32.

Tébar, Lorenzo. (2011). O perfil do professor mediador: Pedagogia da Mediação. Tradução de Priscila Pereira Mota. São Paulo: Editora Senac.

\section{How to cite this article (APA):}

Nascimento, M.C.D.; Amorim, G.G. (2017). The Enviroment Education in Pratice: Challenges ahead Legislation. Am. In. Mult. J., March. 1 (2), 31-44.

Received: 2016/11/5

Accepted: 2016/12/12 